\title{
Importance of umbilical cord examination in neonates
}

\author{
Jogender Kumar 지, ${ }^{1}$ Monisha Rameshbabu, ${ }^{1}$ Muneer Abas Malik, ${ }^{2}$ Praveen Kumar ${ }^{1}$
}

${ }^{1}$ Pediatrics, Post Graduate Institute of Medical Education and Research, Chandigarh, India ${ }^{2}$ Pediatric Surgery, Post Graduate Institute of Medical Education and Research, Chandigarh, India

\section{Correspondence to}

Praveen Kumar;

drpkumarpgi@gmail.com

Accepted 2 June 2020

\section{DESCRIPTION}

A vaginally delivered, term infant presented on the fourth day of life with lethargy, abdominal distension and bilious vomiting. He accepted breastfeeds and passed meconium on the first day. However, on the second day, he developed rapidly increasing abdominal distension, non-bilious vomiting and refusal to feeds for which he was admitted at a nursing home and received antibiotics, intravenous fluid and other supportive care. Abdominal radiograph showed dilated bowel loops (figure 1). However, within 12 hours, he developed respiratory distress and shock requiring intubation and inotropes. The infant was referred to us with a possibility of severe sepsis with intestinal obstruction.

At admission, he had generalised abdominal distension and absent bowel sounds. On examination, we noticed thickened, gangrenous and foulsmelling umbilical cord (figure 2). There was no evidence of omphalitis/abdominal wall cellulitis. Also, there was a swelling, covered with the skin arising from the base of the cord. Therefore, the possibility of accidental clamping and laceration of bowel were considered. Abdominal radiograph showed air-fluid level with a gaseous shadow in the umbilical cord suggesting entrapped intestinal loop (figure 3). These findings confirmed the diagnosis of umbilical cord hernia (UCH) with an intestinal laceration. The baby underwent urgent exploratory laparotomy. Resection of the gangrenous bowel margins followed by an end-to-end anastomosis was done, and the abdomen was closed in layers. There were no other associated malformations. Unfortunately, the baby developed severe sepsis and died on the second postoperative day.

$\mathrm{UCH}$ is an under-reported entity with an estimated incidence of 1:5000. ${ }^{1}$ It is often misdiagnosed

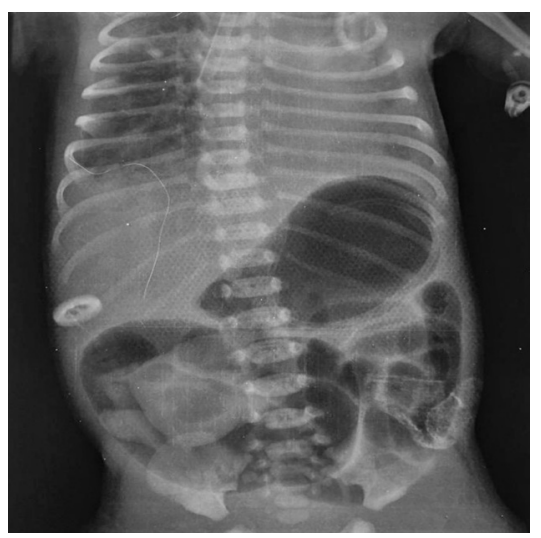

Figure 1 Plain abdominal radiograph showing dilated bowel loops.

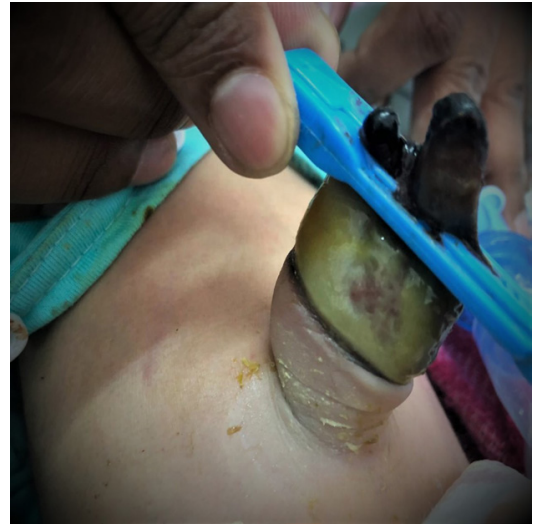

Figure 2 Anterior view showing clamped, thick, oedematous and gangrenous umbilical cord.

as 'omphalocele minor' due to similarities in appearance but can be distinguished by the careful examination of the morphologic characteristics of umbilical cord insertion. ${ }^{2}$

An omphalocele result from primary failure of the body folds to form the umbilical ring, thus creating an abdominal wall defect, whereas, in $\mathrm{UCH}$, the abdominal wall and umbilical ring are intact. In omphalocele, the rectus muscles have a broad insertion laterally on the costal margins instead of meeting in the midline at the xiphoid, as seen in UCH. Moreover, in omphalocele, the umbilical cord has a characteristic abnormal insertion at the top of the herniated sac, whereas, in $\mathrm{UCH}$, the bowel herniates into the base of a normally inserted umbilical cord. ${ }^{1-3}$

Embryologically, omphalocele occurs earlier than UCH. Normally, the intestines elongate into the umbilical coelom at about 5 weeks and returns to the peritoneal cavity between 10 and 12 weeks of gestation. Interruption of this process results in



Figure 3 Abdominal radiograph showing air-fluid level (left) and gaseous shadow herniating into umbilical cord (lateral view). 
an UCH. ${ }^{12}$ Umbilical cord gangrene can be a manifestation of umbilical sepsis if there are features of omphalitis or local cellulitis, which were not seen in index case. ${ }^{4}$

Healthcare providers should carefully examine the umbilical cord and should apply clamp $3-5 \mathrm{~cm}$ from the base. In the presence of any swelling at base or thick oedematous cord, the clamp should be applied $5-6 \mathrm{~cm}$ away from the visible margin of the swelling. ${ }^{5}$ In most cases, it is an isolated anomaly, therefore carries a good prognosis. But in some instances, it may be

\section{Learning points}

- Umbilical cord contents should be carefully examined before clamping. The unmindful cord clamping may lead to devastating complications like intestinal laceration and gangrene.

- Cord examination is an essential part of newborn examination.

- Careful clinical examination can help in differentiating umbilical cord hernia and omphalocele minor

- If intestine is accidentally clamped, early identification and urgent exploration have favourable outcomes.

- Umbilical cord hernia carries good prognosis unless it is associated with gastrointestinal anomalies. associated with malrotation, atresia or Meckel's diverticulum. Therefore, except for the spontaneously reducing varieties, rest would require surgical exploration. ${ }^{3}$

Contributors MR and JK were involved in medical management and MAM did the surgical management. JK and MR drafted the manuscript. MAM and PK reviewed and revised the manuscript. All the authors approved the final version of the manuscript.

Funding The authors have not declared a specific grant for this research from any funding agency in the public, commercial or not-for-profit sectors.

Competing interests None declared.

Patient consent for publication Parental/guardian consent obtained.

Provenance and peer review Not commissioned; externally peer reviewed.

\section{ORCID iD}

Jogender Kumar http://orcid.org/0000-0002-0464-9689

\section{REFERENCES}

1 Raju R, Satti M, Lee Q, et al. Congenital hernia of cord: an often misdiagnosed entity. BMJ Case Rep 201510.1136/bcr-2015-209642. [Epub ahead of print: 21 Apr 2015].

2 Haas J, Achiron R, Barzilay E, et al. Umbilical cord hernias: prenatal diagnosis and natural history. J Ultrasound Med 2011;30:1629-32.

3 Shukla RM, Ray A, Sisodiya N, et al. Look twice before you clamp the cord: iatrogenic ileal transection. J Obstet Gynaecol India 2014;64:40-1.

4 Stunden RJ, Brown RA, Rode $\mathrm{H}$, et al. Umbilical gangrene in the newborn. J Pediatr Surg 1988;23:130-4.

5 Narasimhan KL, Samujh R, Rao KL, et al. Do not clamp the umbilical cord too close. Indian Pediatr 1991;28:565-6.

Copyright 2020 BMJ Publishing Group. All rights reserved. For permission to reuse any of this content visit https://www.bmj.com/company/products-services/rights-and-licensing/permissions/

BMJ Case Report Fellows may re-use this article for personal use and teaching without any further permission.

Become a Fellow of BMJ Case Reports today and you can:

- Submit as many cases as you like

- Enjoy fast sympathetic peer review and rapid publication of accepted articles

- Access all the published articles

- Re-use any of the published material for personal use and teaching without further permission

\section{Customer Service}

If you have any further queries about your subscription, please contact our customer services team on +44 (0) 2071111105 or via email at support@bmj.com.

Visit casereports.bmj.com for more articles like this and to become a Fellow 